O’TANOV. Kh.Sh.

Teacher of the National University of Uzbekistan

x.utanov@mail.ru

\title{
SOME CHARACTERISTICS OF THE LOCAL GOVERNMENT SYSTEM IN THE EMIRATE OF BUKHARA (XVIII-XX CENTURIES)
}

Annotation: Studying the history of administration system in the Emirate of Bukhara which has a special place in the history of the Uzbek statehood shows particular importance. The article discusses the interdependence between the central and local governments, the occupation system of Uzbek sects and their political activities in the Emirate. In addition, provisional administrative and territorial division of economic opportunities in the country facilitated the collection of taxes. The formation of the regular army by the Mangitian rulers and the formation of the class of officials in dealing with religious and legal issues in the local government testify to the systemic and traditional implementation of the administration during this period.

Key words: Beklik, qushbegi, urug', Emir, amlok, tanob, tuman, hazora, nimhazora, qariya, obxo 'ri, maraza, qozi, muftiy, rais, yassovul, mirza, devonbegi, mirshab, oqsaqol, aminonachi, alamgir, navkar, mirohur, xudaychi, bakovul, shabgard, mulla azoim, zakoti chakana, qo 'sh puli, yaksara, dekshu, sais.

The statehood of Uzbekistan has a rich history, to harmonize its long-standing theoretical and legal experience with modern, democratic, legal values and their wider and more effective use in society is one of the actual issues. Therefore, studying the history of the Empire of Bukhara as well as administration system, which is a specific period in the history of our national statehood, is considered to be one of the most important issues of history of statehood and political and legal education.

Despite the existence of important historical sources reflecting the history of public administration in the Bukhara Emirate, especially in the local government, 
the legal foundations of their activity, as well as a lot of scientists such as D.A.Alimova, A.Azizkhodjaev, V.V.Bartold, S.Beker, H.Z. Ziyoev, L.E.Krestovskiy, D.Logofet, E.Meyendorf, A.R.Mukhamadjonov, A.Ziyo, A.N.Nechaev, N.K.Norkulov, K.Rajabov, M.Xoldsvort, R.Halikova and others[1] learned foundation, the state system and historical processes of Bukhara Emirate and published those issues in their works and monographs, the following aspects of it were ignored. In particular, in the period of the Soviet Union, those issues were reflected in terms of the interests and needs of one-sided, dominant ideology. Saying precisely, there was an ideology that rules of holding positions in the local administration of the Emirate and operating of officials were on the basis of the bribe and corruption. The relationship between the central and local government of the Emirate, the correspondence between the local beks and the rulers, and its rules were ignored. The dependency from the central government to the lower administrative apparatus of the Bukhara Emirate has not been fully studied by historian researchers and learned as a secondary issue (especially lower administration tier). Therefore, it is necessary to study the scientific works about the Bukhara Emirate, which dates back to the 19th century to the beginning of the 20th century, the central and local government procedures, the subordinate administrative units, and the role of military and administrative and religious officials in the public administration.

Positions and their giving procedures. It is well-known that in the Bukhara Emirate, local officials were appointed from the members of the Mangit tribe. At the same time, it is noteworthy that those who did not belong to the Mangite and other Uzbek sects were occupied with high positions in the local government during this period [2]. The ruler was constantly reported by the territorial structures. The governors and judges of all the capitals of the Emirates sent information to Emir by the help of navkars and chopars. They were given gratitude on behalf of the Emir [3].

It should be noted that a number of measures were taken to ensure the safety of citizens in the Emirate. In particular, a number of positions were introduced in 
order to protect citizens from theft, thieves, occupiers, and various insurgents. For instance, zindonband, jilband, jallod va bandiband and other officials [4]. The Emir or his appointed officials, the representative of Emir, administrators and the beks were the local government agencies. The beks were from the upper class and were appointed mainly among large landowners.

As a rule, ranks were based on kinship but some cases ordinary citizens' achievement of bek level indicates that administration of beklik is a responsible task.

Local government executives used to introduce a centralized governance approach in administration. Therefore, in some parts of the Emirate there were occasional occurrences of ignorance of existing power. Each of beks had his palace, position, and rank. Beks had the secretaries for the affairs of management and coordination, and they controlled taxes and other mandatory payments in the regions. Economic affairs were managed by the treasurer named as dastukhanchi. Bekliks differed according to their legal status in the Emirates of Bukhara. For example, the Beklik of Samarkand because of its prestige, the Beklik of Karshi because of the authority of the heir of the head of the state, the beklik of Bukhara because of being ruled by kushbegi, they had extensive privileges.[6]

Generally speaking, the status of the bekliks depended on the amount of benefits they made for the state and society. Beks earned from mainly rentals because they did not get any fees from the Emir. In turn, they were responsible for tax and other mandatory payments. The beks were counted as officials of the Emir, and they were appointed by the decree [7] and they accounted for the economic, social and political issues of territorial units.

Administrative-territorial division. It is noted that during the rule of Mangits dynasty, the administrative-territorial structure of Emirate comprised of 27 bekliks and 11 districts [8]. N. Kislyakov pointed to the administrative division of the Bukhara Emirate, saying that at the beginning of the 20th century, administrative division of the country was divided into 24 bekliks, 7 separate amlokliks and 10 districts [9]. Professor Eshov describes the territorial division of 
the Emirate in the middle of the XIX century as follows: 100,000 tan irrigated land was called tuman, 50,000 tan irrigated land was called khazora, 25,000 tan irrigated land was called nimkhazora, 10,000-15,000 hectares of irrigated lands was called obkhoriga, the name of 400 hectares of irrigated land was kariya, 300 hectares of irrigated land was called maraza(ekinzor)[10].

In our opinion, this was not a formal administrative division, but a provisional administrative-territorial division aimed at identifying the economic potential of the country. Such kind of separation created the convenience and specific order in taxation.

All the beks were personally appointed and dismissed by the Emir [11]. After the beks had been appointed, they used to give lucrative position of the castle to their relatives and loyal ones. The authority of beks was not inherited from generation to generation. In the event of bek's death, his property was transferred to the Emirate treasury, and his heirs did not receive a share. Each bek independently governed the territory on his own, and the bek's wish was the law in that place.

It also coincided with uniting some territories or vice versa in order to eliminate the existing disagreements. There were many administrative positions at the Bek's Palace. It is noteworthy that in spite of the fact that the positions in bekliks did not depend on the number of the inhabitants of the region, the number of administrative officials did not decrease even in some poor economic regions. For example, even though there were about 55,000 inhabitants in Darvoz where was considered one of the poorest region of bekliks, the number of local government officials was relatively high [14]. In the Bukhara Emirate, bekliks and districts were divided into administrative-territorial units in different ways. Many bekliks comprised of several amloks including villages. Several bekliks and districts were divided into mavzes. (for example, Dehnav, Pirmast, Khutfar, Otsi and other regions). In particular, there were some villages in the Khutfar District. At the same time, the territory of one district or region is called the amlok, the 
guzar, mavze and the mosque. Each mavze consisted of territorial units called mosques and the number of them was more than 10 [15].

Sources show that there was almost no difference between the mavze and the village. Only the distinction between the mavze and the rural community was determined in Khutfar district and Karmana beklik. For example, more than half of the mavzes in the Khutfar district consisted of just one village. In the beklik of Karmana, up to thirteen villages were included in each mavze. Generally, the mavze had a large regional units compared to a village or a mosque.

Although the beklik of Karki consisted of several mavzes, they included territorial units, called the bekcha.

The beklik of Nurate was divided into guzars, and in turn guzars divided into the villages. At the same time, the beklik of Karategin consisted of the rabovs, and they were composed of settlements and villages. The beklik of Shugnan and Roshan divided into oksakolliks. Besides, more than 60 residental areas of the beklik of Baljuvon, more than 30 areas of the beklik of Korategin and more than 20 residental areas of the beklik of Kulob consisted of territorial units called dahas.

If we analyze the administrative structure of the Gissar beklik in the eastern Bukhara region, then, according to the rule, the position of bek was occupied by the close relative of Amir Abdulahad's uncle Ostonakulibek. The beklik of Gissar was one of the richest regions of Bukhara's Emirate and as bek was close relative of Emir, he was given the right of imprisonment on the grounds.

Ostonakulbek has a number of officials at his disposal, and all officials in the area were dwelling on the basis of local taxes which were collected from local residents. The money (moyana) given by bek constituted a part of the income of officials. Ostonakulibek ruled the beklik through his kushbegi and a senior yasavulboshi. In addition, there was a special devonkhana in the beklik, which was managed by seven secretaries [16]. At the same time, 25 yasavuls were involved in local government administration to do various functions [17]. Karshi was divided into 15 administrative units, namely amloks. They were Kamashi, Janinov, Kasbi, Maymanak, Koson, Pulaty, Parguza, Fayzabad, Beshkent, Potiron, Fazli, 
Jumabazor, Khanabad, Chim, and Karabag [18]. The beklik of Kitab was divided into 9 amloks. The number of amloks was 14 for the beklik of Shakhrisabz, 11 for the beklik of Yakkabog , 6 for the beklik of Chirakchi, as well as 6 for the beklik of Guzar [19].

According to Mirzo Salimbek's opinion ( who lived in that time), Bektarik, Amloki Duyul, Karabag, Imam Yakub, Bozaryik, Sumak, Toshkurgan, Boboshadi and Koriakoch amloks were situated in the beklik of Yakkabog [20]. In turn, bekliks divided into amloks, they were governed by amlakdors appointed by beks [21]. Amloks consisted of several villages. The amlakdors collected taxes, did other administrative duties in their respective regions. An assistant appointed among representatives of local oksakals, as well as the following worked with amlakdor: mirza-manager, yasavulboshi - the assistant of the amlakdor and the execution of his orders; Devanbegi - engaged in income-expenditure; Aminonachi was responsible for the collection of the tax called aminona from the markets, almagirs worked under his control; mirshab, Aryk oksakal- head of irrigation system; Mirobs - managing irrigation and water distribution; navkars - they promoted from ordinary soldiers up to the position of mirshab; market oksakal collected taxes in the live-stock markets. The lower officials consisted of bakavul, dekshu and siases [22]. The village was governed by the oksakals, elected by the local residents.

The Tajik villages were governed by oksakal, called arbob, and nomadic people were governed by elbegi.

For the purpose of governing local territories and establishing each district, 80 settlements were united. Later, the population of those districts increased. The administrative center of the bekliks in Emirate was named after the same name. The eastern bekliks were dominant, due to the large number of their residential areas. For example, there were 1420 residental areas in Bolivia, there were 1200 in Gissar, 700 in Karate, and 635 in Golob.

In the territory of Turkmenistan, the number of settlements was not many. There were 15 residental area in O'sti, 14 residental area in Burda and 24 in Kelip 
respectively.

The Role of Local Territories to form the Country's Army. Each amlakdor had from 10 to 200 navkars, who were mainly engaged in military service, guarding the palace of beks and officers, and controlling people who had been imprisoned [24]. The social structure of Navkars was diverse and even some of the major landowners were enrolled as navkars. The level of Navkars' position was determined according to their property status. In addition, the navkars who had accomplished their job well were given the right by beks to receive additional payments from some villages [25]. The number of navkars in amlokdorliks was not the same. For example, there were 195 navkars in the amlokdorlik of Esonkhoja 90 navkars in Badrakli, 80 navkars in Gazimalik, 25 navkars in Qoratag and Regar, 24 navkars in Khonaki, 18 navkars in Sarijoy, 13 navkars in Shurkan, 11 navkars in Dashnabad, 8 navkars in Sariosiya and 7 navkars worked in Gissa. There were permanent armored troops in the beklis of Kobul and Karachi, which were not affiliated with local governments [27]. In the bekliks of Denov and Kurgantepa, however, there was not a permanent army of Emir, but the beks relied on the local military force in administration. [28].

Religious and legal governance and public order. Officers such as the judge, the chairman, the mufti and the mirshab were involved in the establishment of local government in bekliks. The judges of the bekliks were directly appointed from Bukhara and were independent of beks in their activities [29]. They were usually secretly sent information to Bukhara about the bek's actions. Religious officials had control of the country's judicial authority, as well as educational establishments, such as madrassahs, primary schools, mosques which was very important in everyday life and other social institutions. By the recommendation of the judges, judges in amlokliks and mulla azim were appointed by Kozi Kalon. Actually, after several years of operation, judges were given firstly the rank of o'rok, then sudur even sadr.

Mirshabs controlled the city's public order. Other cities' mirshabs in Emirate obeyed the mirshab of Bukhara at the same time. Mirshab(rasas) had to do tasks 
related to authority, he was responsible for protection of city. The prisoners of state belonged to him, Amir's shig'avul, khudaychi (udaychi) did not do anything on their own free, and they obeyed the order of Emir. [31]

Bukhara was divided into two dakhas, each of which had six jaribs. Dakhaboshi governed each dakha. And Bobo governed jarib, his office was called bobokhona. At his disposal there were guards who only worked at night and thoso guards were called shabgards (meaning of Shabgard - to go out for a stroll in the city at night, a Persian-language, meaning of shab "night"). Shabgers' main tasks were to walk around the city at night and detect all suspicious persons, as well as take steps to stop and arrest divagating of people at night in the city. The detainees were involved in cleaning streets and bathrooms.

The main task of the mirshabboshi of Bukhara was to walk around at night, to ban games and entertainment and impose a fine on them. In order to ensure peace and security in the city, weddings, celebrations, and other ceremonies were required to end at the set time. This case was taken under control by representatives of the mirshabboshi. [33]

In the local government administration system of Bukhara Emirate, rais was a special position. This practice was a semi-religious, half-disciplined method, and the responsibility of the rais was primarily to control behavior of the population.

Local administration in the study of foreign scientists. Foreign scholars dealing with the issues of statehood in the Bukhara Emirate make almost the same opinion on the central and local administrative divisions of the Emirate. Particularly, J. Kunits said, "The authority of the Emir was absolute. The heads of the various institutions were appointed by him, and he was only responsible for it [34]. In addition, the author points out that the country was divided into administrative unions - regions, districts, and villages and that local administrative officers were called beks, amlokdors and oksakals.

Again, according to the custom of Islam, there were raises and those who obeyed them in each beklik. The finance department was governed by central and local tax 
collectors. Each beklik had its own jurisdiction, which consisted of the chief judge and subordinate judge, as well as the mufti. All the offices were under the command of the Emir[35].

In each beklik, there were six positions belong to judges: mufti - assistant of judge, mirza - secretary, mulla azoim- investigators, housekeepers and servants [36].

English scientist G.Uiler gives the following information about central and local government in the Bukhara Emirate: "The administrative system of the Emirate of Bukhara is inherited from the Iranian-Arabian administration of Movarounnahr under the rule of the Temurids and the Abbasid Caliphate". G.Uiler stated that administration was simple and free, and that it was based on more taxes and favors [37].

It should be noted that central government did not pay special wages to all local authorities. That is why officials accustomed to turning their positions into earnings. Local residents were taxed called zakoti chakana, kosh puli, yaksara, osiya puli, objuvoz puli, tanob puli, alaf puli. Tose taxes were not mentioned in Shariat and were collected primarily for the needs of local authorities and beks [38].

Conclusion. During the reign of the Mangit dynasty, public administration was virtually no different from that of the Shaybani and Ashtar Khan era, and no significant change in the administrative system was observed. The Emir ruled the state based on the central executive power in the palace and the local government system. Socio-economic and political events in the country show that there were changes in the Emirate authority and the administrative division. As a result of analyzing the historical sources of the Bukharian Emirate's local government, the following conclusions are drawn: Firstly, the Emirate state system was based on the rule of the Eastern Monarchy; Secondly, there was a specific system between the central and local authorities and the scope of functions were clearly defined; Thirdly, local self-governance was carried out in different regions of the Emirate; Fourthly, the administration did not allow other officials to 
interfere with other activities; fifthly, all citizens, regardless of their nationality, were able to participate in public administration; Sixthly, the local government was based on a specific system like the central government; seventh; it is important to use the local self-governance practice as a historical practice today.

\section{REFERENCES:}

1. Қаранг: Ўзбекистон давлатчилиги тарихи очерклари/Масъул мухаррирлар: Д.А.Алимова, Э.В.Ртвеладзе. - Тошкент: Шарқ, 2001. - 224 б; Азизхўжаев А.А. Давлатчилик ва маънавият. - Тошкент: Шарқ, 1997. - 112 б; Бартольд. В.В. Узбекские ханства // Сочинения. Т.2. Ч 1. - М.: Наука, 1963. - 1020 с; Бескер С. Букхара анд Кхива. 1865-1924. - Самбридге: 1968. - 416 п; Зиёев Х.3. Туркистонда Россия тажовузи ва хукмронлигига қарши кураш. Тошкент: “Шарк”, 1998; - 185 б; Крестовский Л.Е. В гостях у эмира Бухарского. Соб. соч. Т.VII. - СПб.: Березовский, 1911. - 229 с; Логофет Д.И. Бухарское ханство под русским протекторатом. - СПб.: Березовский, 1911. 332 с; Мейендорф Е.К. Путешествие из Оренбурга в Бухару. - М.: Наука, 1975. - 182 с; Мухамеджанов А.Р. Населенные пункты Бухарского эмирата (конец XIX - нач. XX вв.) - Ташкент: Университет, 2001. - 415 с; Зиё А. Ўзбек давлатчилиги тарихи: (энг қадимги даврдан Россия босқинига қадар). Тошкент: Шарқ, 2001. - 386 б; Нечаев А.В. По горной Бухаре. Путевые очерки. - СПб.: 1914. - 107 с; Норкулов Н.К. “Тарихи Салимий” - ценный источник по истории Бухарского эмирата: (1860-1920). Автореф. дис....канд. ист. наук. - Ташкент: 1968. - 24 с; Ражабов Қ. Амир Хайдар ёхуд Амири Саййид // Бухоро мавжлари. - Бухоро, 2006. - № 2. -Б.40-42; Холдсwортх М. Туркестан ин тхе нинетеентх сентурй. А бриеф Хисторй оф Кханатес оф Сентрал Асиа. - Охфорд: 1959. - 80 п; Холиқова Р. Марказий давлат бошқаруви тарихига бир назар // Мулоқот. -Т.: 2004. - № 4.- Б.41-42. 
2. Амир Саййид Олимхон. Бухоро халқининг хасрати тарихи / Форсийдан таржима, муқаддима ва изохлар муаллифи А. Ирисов. - Т.: Фан, 1991. - Б.26.

3. Чехович О.Д. Документы к истории аграрных отношений в Бухарском ханстве XVII - XIX вв. - Ташкент: Изд. Акад. Наук Уз ССР, 1954. - C.183.

4. Шодиев Ж. М. Бухоро амирлигининг ташкил топиши ва давлат тузуми. Юридик фан. номзоди ... дисс. - Тошкент: ТДЮИ, 2008. - Б. 78.

5. КрестовскийЛ.Е. В гостях у эмира Бухарского. Соб. соч. Т.VII. - СПб.: Березовский, 1911. - С.173.

6. Ханыков Н. Описание Бухарского ханства. - СПб.: Типография Императорской Академии Наук, 1843. - С.187.

7. Тухтаметов Т.Г. Россия и Бухарский эмират в начале XX века. - Душанбе: Ирфон, 1977. - С.16.

8. ЎзР МДА, 126-жамғарма, 1-рўйхат, 51-иш, 43-варақ; Населенные пункты Бухарского эмирата (конец ХИХ - нач. XX вв.). / Под ред. А.Р.Мухаммеджанова.-Т.: Университет,2001.-С. 5.

9. ЎзР МДА, 1-жамғарма, 29-рўйхат, 571-иш, 1-2 -варақ.

10. Эшов Б. Ўзбекистонда давлат ва махаллий бошқарув тарихи. - Т.: Янги аср авлоди, 2012. - Б. 345.

11. Логофет Д.Н. Бухарское ханство под русским протекторатом. - СПб., 1911. - Т. И.- С.240.

12. ЎзР МДА, 2-жамғарма, 1-рўйхат, 251-иш, 87-варақ.

13. Яворский И.Л. Путешествие русского посольства по Афганистану и Бухарскому ханству в 1876-1879гг.// Туркестанский сборник. - СПб., 1882.C. 36 . 
14. Логофет Д.Н. Бухарское ханство под русским протекторатом. - СПб., 1911. - Т. И.- С. 242.

15. Населенные пункты Бухарского эмирата(конец XIX- нач. XX вв.)./Под ред. А.Р.Мухаммеджанова. Ташкент: Университет, 2001. - С.5.

16. Шодиев Ж. М. Бухоро амирлигининг ташкил топиши ва давлат тузуми. Юридик фан. номзоди ... дисс. Тошкент: ТДЮИ, 2008. - Б. 79.

17. Искандаров Б.И. Из истории Бухарского эмирата. М.: Изд-во. Вос. Литры, 1958. - C.18.

18. Кисляков Н.А. Патриархально-феодальные отношения среди оседлого сельского населения Бухарского ханства в конце XIX-начале XX в. М. Л.: AH CCCP, 1962. -C.54.

19. Очилдиев Ф.Б. XIX-XX аср бошларида Жанубий Ўзбекистонда ижтимоийиқтисодий хаёт: Тарих фан. номзоди...дисс. Т.: ЎзМУ, 2007.- Б.102.

20. Мирза Салимбек. Тарих-и Салими.Ташкент: Академия, 2009. - С. 96, 128.

21. Холикулов А.Б. XIX-XX аср бошларида Қашқадарё бекликлари. Тарих фан. номзоди ... дисс. Тошкент: ЎзМУ, 2011. - Б. 121.

22. Логофет Д.Н. Бухарское ханство под русским протекторатом. СПб., 1911. - Т. И.С. 243-244.

23. Холикулов А.Б. XIX-XX аср бошларида Қашқадарё бекликлари. Тарих фан. номзоди ... дисс. Тошкент: ЎзМУ, 2011. - Б.122.

24. Шодиев Ж. М. Бухоро амирлигининг ташкил топиши ва давлат тузуми. Юридик фан. номзоди ... дисс. Тошкент: ТДЮИ, 2008. - Б. 79.

25. Холикулов А.Б. XIX-XX аср бошларида Қашқадарё бекликлари. Тарих фан. номзоди ... дисс. Автореф. Тошкент: ЎзМУ, 2011. - Б. 22.

26. “Туркестанские ведомости”. 1908. 27 мая. 
27. Бейсембиев Т.К. Малые владения в Мавараннахре: Нур-ата, Ургут, Яккабаг (XIII-ХІХвв.) // Иран-намэ. Научный востоковедческий журнал. Алматы, 2007. № 1. - С. 23,24.

28. Ахмад Дониш. Трактат Ахмада Дониша «История мангитской династии» / Пер., предисл. и примеч. И.А.Наджафовой, отв. редактор А.М.Беленицкий. Душанбе: Дониш. 1967. - С. 76.

29. Тухтаметов Т.Г. Россия и Бухарский эмират в начале XX века. - Душанбе: Ирфон, 1977. - С.17.

30. Вохидов Ш. Кўқон хонлиги ва Бухоро амирлигида унвон ва мансаблар. Т.: 1996. - Б. 26.

31. Мухаммадхакимхон туура. Мунтахаб ат-таворих / Форс-тожик тилидан тарж., муқаддима, изохлар ва кўрсаткичлар муаллифи Ш.Вохидов. Тошкент: Янги аср авлоди, 2010. - Б. 519.

32. Холикова Р.Э. ХІХ аср иккинчи ярми-XX аср бошларида Россия - Бухоро муносабатлари тарихи: Тарих фан. доктори ... дисс. Тошкент: ЎзМУ, 2006. Б.205.

33. Шодиев Ж. М. Бухоро амирлигининг ташкил топиши ва давлат тузуми. Юридик фан. номзоди ... дисс. Тошкент: ТДЮИ, 2008. - Б. 81.

34. Kunits J. Dawn of Samarqand. The rebirth of Central Asia. New York: CoviciFriede, 1935. - R.22.

35. Kunits J. Dawn of Samarqand.The rebirth of Central Asia. New York: CoviciFriede, 1935. - R.23.

36. Холиқулов А.Б. ХІХ-XX аср бошларида Қашқадарё бекликлари. Тарихфан. номзоди ... дисс. автореф. Тошкент: ЎзМУ, 2011. -Б.22.

37. Wheeler G. Modern history of Soviet Central Asia. London: Weidenfeld and Nicolson, 1964. - P.43. 
38. Логофет Д.Н. Бухарское ханство под русским протекторатом. СПб.: Б.И., 1911. -T. II. -C.53. 